\title{
PERILAKU PENGGUNA TERHADAP SISTEM GURU PEMBELAJAR ONLINE DI SEKOLAH MENENGAH PERTAMA NEGERI KOTA PALEMBANG
}

\author{
Fitria Apriani' ${ }^{1}$, Muhammad Izman Herdiansyah ${ }^{2}$, Diana $^{3}$ \\ Program Magister Teknik Informatika \\ Universitas Bina Darma \\ email :fhitria.apriani0493@gmail.com,m.herdiansyah@binadarma.ac.id, \\ diana@binadarma.ac.id \\ J1. A. Yani No. 12, Palembang 30624, Indonesia
}

\begin{abstract}
GPO (Online Learning Teacher) is a program developed by Kemdikbud post-UKG (Teacher Competency Exam) 2015 which aims to improve teacher competence. Learning Teachers Online mode consists of 3 (three) models: GP Full Dedicated Mode, GP Front Facing Mode and GP Combination Mode Mode. In the application of the GP program does not necessarily run as planned, while the conditions that occur in the field to meet the problems in the application, due to factors that affect users GP program itself, such as the use of information technology used is sometimes considered by some teachers as a difficulty due to lack of knowledge will be computer technology. Unified Theory of Acceptance and Use of Technology (UTAUT) states that one's acceptance of information technology (user intention). two variables of research that variables have significant effect to behavioral intention, effort expectancy have significant effect to behavioral intention and facilitating condition correlate positively to user behavior and three other variables that is social influence, no significant influence on behavioral intention and behavioral intention unrelated posistif with user interest User Behavioral) Online Teacher Learning System (GPO) system system of Junior High School teachers.
\end{abstract}

Kata Kunci : Behavior Itention, GPO, UTAUT, User Behavior

\begin{abstract}
GPO (Guru Pembelajar Online) merupakan Program yang dikembangkan oleh Kemdikbud pasca UKG (Ujian Kompetensi Guru) tahun 2015 lalu yang bertujuan untuk meningkatkan kompetensi guru. Guru Pembelajar Moda daring ini terdiri dari 3 (tiga) model yaitu GP Moda Daring Penuh, GP Moda Tatap muka dan GP Moda Daring Kombinasi. Dalam penerapannya program GP tidak serta merta berjalan sesuai rencana, sedangkan keadaan yang terjadi dilapangan menemui kendalam dalam penerapannya, dikarenakan faktor-faktor yang mempengaruhi pengguna program GP sendiri, seperti faktor penggunaan teknologi informasi yang digunakan yang terkadang dianggap oleh beberapa guru sebagai kesulitan dikarenakan kurangnya pengetahuan akan teknologi komputer. Unified Theory of Acceptance and Use of Technology (UTAUT) menyatakan bahwa penerimaan seseorang terhadap teknologi informasi (user Intention). dua varibel penelitian yaitu varibael berpengaruh signifikan terhadap behavioral intention, effort
\end{abstract}


expectancy berpengaruh signifikan terhadap behavioral intention dan facilitating condition berhubungan positif terhadap user behavior dan tiga variabel lainnya yaitu social influence, tidak berpengaruh signifikan pada behavioral intention dan behavioral intention tidak berhubungan posistif dengan minat pengguna (User Behavioral) sistem sistem Guru Pembelajar Online (GPO) guru Sekolah Menengah Pertama (SMP).

Kata kunci:Behavior Itention, GPO, UTAUT, User Behavio

\section{PENDAHULUAN}

Guru memiliki tugas, fungsi, dan peran yang penting dalam mencerdaskan kehidupan bangsa. Supaya dapat melaksanakan tugas, fungsi dan peran tersebut, guru perlu untuk meningkatkan profesionalismenya secara berkelanjutan. Kementerian Pendidikan dan Kebudayaan mengembangkan program kegiatan Guru Pembelajar (GP) guna langkah mengaktualisasikan guru professional pengajarPengembangan program kegiatan Guru Pembelajar dilakukan sebagai metode pembelajar untuk meningkatkan profesionalisme guruguru dengan melakukan evaluasi materi-materi dari setiap guru yang meliputi setiap mata pelajaran yang ada sesuai dengan guru pengajar masing-masing. Berdasarkan Indikator Pencapaian Kompetensi (IPK) dalam SKG dikembangkan peta kompetensi guru yang dibagi menjadi 10 kelompok kompetensi. Karena jumlah guru yang banyak dan tersebar di seluruh Indonesia, maka dikembangkan sistem program kegitan GP secara elektronik dengan memanfaatkan Teknologi Informasi dan Komunikasi (TIK), yang kemudian disebut Guru Pembelajar Moda Daring (dalam jaringan). Moda daring guru pembelajar terdapat 3 bagianyaitu Guru pembelajar Moda Daring Penuh-Model 1, Guru pembelajar Moda Daring Penuh-Model 2, dan Guru Pembelajar Moda Daring Kombinasi.

Salah satu faktor penentu keberhasilan dalam penerapan sebuah sistem yaitu ketika sistem dapat diterima dengan baik oleh pengguna. Pengguna terbesar dalam sistem GPO ini adalah guru sehingga data terbesar yang terekam dan terbanyak untuk dijadikan sebagai bahan evaluasi adalah guru, namun pada penelitian ini evaluasi akan dilakukan pada guru Sekolah Menengah Pertama (SMP).Evaluasi pengguna terhadap sistem GPO ini dilakukan karena teknologi tanpa diimbangi dengan kemampuan operator (pengguna) yang memanfaatkannya akan mengurangi fungsi dan manfaat dari teknologi tersebut, selain itu evaluasi pengguna dilakukan untuk mengetahui faktor-faktor yang mempengaruhi penerimaan pengguna sistem GPO tersebut. Kondisi tersebut menyebabkan teknologi informasi dan komunikasi bukannya akan memberikan keuntungan namun sebaliknya akan menimbulkan infisiensi.

Salah satu teori yang digunakan sebagai acuan dalam penerimaan perilaku pengguna terhadap sistem GPO adalah Unified Theory of Acceptance and Use of Technology (UTAUT) yang dikembangkan oleh Venkatesh et,al(2003). UTAUT memiliki konstrak model yang menjadi landasan analisis factor para penerimaan pengguna sistem. Faktor-faktor ataupun konstruk dalam UTAUT yang antara lain adalah Performance Expectancy (PE), Effort Expectancy (EE), Social Influence (SI), Facilitatng Conditon (FC), Behavioral Intenton (BI). Dalam penelitian Sedan dan Wijaya (2010), Handayani (2007), Sedan dan WIjaya (2009), Bendi dan Andayani (2013), Putra dan Ariyanti (2017), Beni dan Andayani (2013), Jairak et.al., (2009) melakukan penelitian dengan menggunakan teori UTAUT untuk menganalisis tentang perilaku pengguna sistem dengan menggunakan model UTAUT.UTAUT telah digunakan untuk meneliti berbagai jenis inovasi teknologi di seluruh dunia baik yang bersifat organisasi (continuous monitoring technology, clinical decision hingga information system) maupun bersifat consumer use (mobile shopping service, MRT I-Pass, mobile internet dan mobile banking).Dari latar belakang tersebut penulis ingin melakukan penelitian yang berjudul "Analisi 
Perilaku Pengguna Terhadap Sistem Guru Pembelajar Online (Studi Kasus : Guru SMP Negeri Di Kota Palembang)".

\section{LANDASAN TEORI}

Dalam sebuah penelitian landasan teori dibutuhkan untuk mendasari penjelasan ilmiah atau sebagai acuan dalam menjelaskan dasar-dasar dari penelitian itu sendiri. Landasan teori ini didasarkan pada analisis penelitan yang membantu pembaca lannya dalam melakukan pemahaman akan isi penelitian, dalam penilitian ini landasan teori didasarkan pada GPO (Guru Pembelajar Online) dan UTAUT sebagai metode penelitian yang akan digunakan, beriku adalah penjelasan dari teri yang akan digunakan dalam penelitian ini :

\subsection{Guru Pembelajar Online (GPO)}

Guru Pembelajar Online (GPO) merupakan program pemerintah yang diterapkanUntuk merealisasikan amanah undang-undang sebagaimana dimaksud, KementerianPendidikan dan Kebudayaan melaksanakan Program Peningkatan Kompetensi GuruPembelajar bagi semua guru, baik yang sudah bersertifikat maupun belum bersertifikat (Kementerian Pendidikan dan Kebudayaan, 2016). Program Peningkatan Kompetensi Guru Pembelajar adalah upaya peningkatankompetensi guru yang melibatkan Pemerintah serta partisipasi publik yang meliputipemerintah daerah, asosiasi profesi, perguruan tinggi, dunia usaha dan dunia industri,organisasi kemasyarakatan, serta orangtua siswa.

Peningkatan kemampuan tersebutmencakup kegiatan-kegiatan yang bertujuan untuk perbaikan dan pertumbuhankemampuan (abilities), sikap (attitude), dan keterampilan (skill). Program Peningkatan Kompetensi Guru Pembelajar dirancang berdasarkan StandarKompetensi Guru (SKG) yang mengacu pada Permendiknas Nomor 16 Tahun 2007tentang Standar Kualifikasi Akademik dan Kompetensi Guru, Permendiknas Nomor 27Tahun 2008 tentang Standar Kualifikasi Akademik dan Kompetensi Konselor,Permendiknas Nomor 32 Tahun 2008 tentang Standar Kualifikasi Akademik danKompetensi Guru Pendidikan Khusus, dan Permendikbud Nomor 137 Tahun 2014tentang Standar Nasional Pendidikan Anak Usia Dini.

Standar Soal Tes AkhirSoal tes akhir program peningkatan kompetensi guru pembelajar berupa tes objektif yang disusun berdasarkan Indikator Pencapaian Kompetensi (IPK) yang tercantum pada kelompok kompetensi modul yang dilatihkan. Jumlah soal untuk satu kelompok kompetensi sebanyak 30 butir soal, dengan proporsi 10 soal pedagogik dan 20 soal profesional. Uji validitas soal dilakukan dengan menggunakan validasi konstruk dan konten oleh pakar.

\subsection{Unified Theory of Acceptance and Use of Technology (UTAUT)}

Unified Theory of Acceptance and Use of Technology (UTAUT) merupakan metode yang dikembangkan oleh Vankatesh et.al (2003). UTAUT merupakan salah satu model yang dapat digunakan untuk menjelaskan penerimaan pengguna (user acceptance) dalam bidang sistem informasi karena UTAUT mensintesis elemen-elemen pada delapan model penerimaan teknologi terkemuka untuk memperoleh kesatuan pandangan mengenai penerimaan pengguna (Sedana dkk, 2009).BerdasarkanUTAUTmenggabungkan fitur-fitur yang berhasil daridelapan teori penerimaan teknologi terkemukamenjadi satu teori. Pada tabel 1 merupakankedelapan teori terkemukayang mendasari UTAUT, beriku adalah tabel kedelapa terori tersebut : 
Tabel 1 Teori-teori konstruk yang mendasari UTAUT

\begin{tabular}{|c|c|c|c|}
\hline No & Nama Teori & $\begin{array}{c}\text { Peneliti } \\
\text { (Tahun Penelitian) }\end{array}$ & Pengertian \\
\hline 1 & $\begin{array}{c}\text { Theory of Reasoned } \\
\text { Action (TRA) }\end{array}$ & $\begin{array}{l}\text { Fishbein dan } \\
\text { Azjen (1975) }\end{array}$ & $\begin{array}{l}\text { Teori untuk memprediksi perilaku manusia } \\
\text { yaitu dengan cara menganalisis hubungan antara } \\
\text { berbagai kriteria kinerja dan sikap seseorang, } \\
\text { niat, dan norma subyektif. }\end{array}$ \\
\hline 2 & $\begin{array}{l}\text { Theory of Planned } \\
\text { Behavior (TPB) }\end{array}$ & Ajzen (1988) & $\begin{array}{l}\text { Teori yang digunakan untuk memenuhi keadaan } \\
\text { ketika perilaku seseorang tidak sukarela dengan } \\
\text { memasukkan prediktor niat dan perilaku yang } \\
\text { mengacu pada keyakinan tentang adanya factor } \\
\text { yang dapat memfasilitasi atau menghalangi } \\
\text { kinerja suatu perilaku tertentu. }\end{array}$ \\
\hline 3 & $\begin{array}{l}\text { Technology } \\
\text { Acceptance Model } \\
\text { (TAM) }\end{array}$ & $\begin{array}{l}\text { Davis F.D } \\
\text { (1989) }\end{array}$ & $\begin{array}{l}\text { Mengidentifikasi reaksi dan persepsi seseorang } \\
\text { terhadap suatu yang menentukan sikap dan } \\
\text { perilaku orang tersebut dengan cara membuat } \\
\text { model perilaku seseorang sebagai suatu fungsi } \\
\text { dari tujuan perilaku dimana tujuan perilaku } \\
\text { ditentukan oleh sikap atas perilaku tersebut. }\end{array}$ \\
\hline 4 & $\begin{array}{l}\text { Motivational Model } \\
\text { (MM) }\end{array}$ & $\begin{array}{l}\text { Davis, et al. } \\
\quad(1992)\end{array}$ & $\begin{array}{l}\text { Teori motivasi yang dikembangkan untuk } \\
\text { memprediksi penerimaan dan penggunaan } \\
\text { teknologi. }\end{array}$ \\
\hline 5 & $\begin{array}{l}\text { Combined TAM and } \\
T P B(\mathrm{C}-\mathrm{TAM}-\mathrm{TPB})\end{array}$ & $\begin{array}{l}\text { Taylor dan } \\
\text { Todd (1995) }\end{array}$ & $\begin{array}{l}\text { Model hibrida dari TPB dengan TAM yang } \\
\text { memberikan penjelasan akurat mengenai } \\
\text { penentu penerimaan dan perilaku penggunaan } \\
\text { suatu teknologi tertentu. }\end{array}$ \\
\hline 6 & $\begin{array}{c}\text { Model of PC } \\
\text { Utilization (MPCU) }\end{array}$ & $\begin{array}{l}\text { Thompson, et } \\
\text { al. (1991) }\end{array}$ & $\begin{array}{l}\text { Menilai pengaruh dari kondisi kondisi yang } \\
\text { mempengaruhi dan memfasilitasi, faktor sosial, } \\
\text { kompleksitas, kesesuaian tugas dan konsekuensi } \\
\text { jangka panjang terhadap pemanfaatan } P C \text {. }\end{array}$ \\
\hline 7 & $\begin{array}{l}\text { Innovation } \\
\text { Diffusion Theory } \\
\text { (IDT) }\end{array}$ & $\begin{array}{c}\text { Rogers } \\
(1962)\end{array}$ & $\begin{array}{l}\text { Diadopsi dari penerapan teknologi IDT dapat } \\
\text { mengukur persepsi masyarakat dengan } \\
\text { menggunakan tujuh atribut kunci. }\end{array}$ \\
\hline 8 & $\begin{array}{l}\text { Social Cognitive } \\
\text { Theory (SCT) }\end{array}$ & $\begin{array}{c}\text { Bandura } \\
(1977)\end{array}$ & $\begin{array}{l}\text { Mengidentifikasi perilaku manusia sebagai } \\
\text { interaksi dari faktor pribadi, perilaku, dan } \\
\text { lingkungan yang bertujuan memberikan } \\
\text { kerangka untuk memahami, memprediksi, dan } \\
\text { mengubah perilaku manusia. }\end{array}$ \\
\hline
\end{tabular}

Setelah melalui pengujian lebih lanjut, merekamenemukan empat konstruk utama yangmemainkan peran penting sebagai determinanlangsung dari behavioral intention dan usebehavior yaitu, performance expectancy, effortexpectancy, social influence, dan facilitatingconditions. Sedangkan yang lain tidak signifikansebagai determinan langsung dari behavioralintention. Disamping itu terdapat pula empatmoderator: gender, age, voluntariness, danexperience yang diposisikan untuk memoderasidampak dari empat konstruk utama padabehavioral intention dan use behavior. 


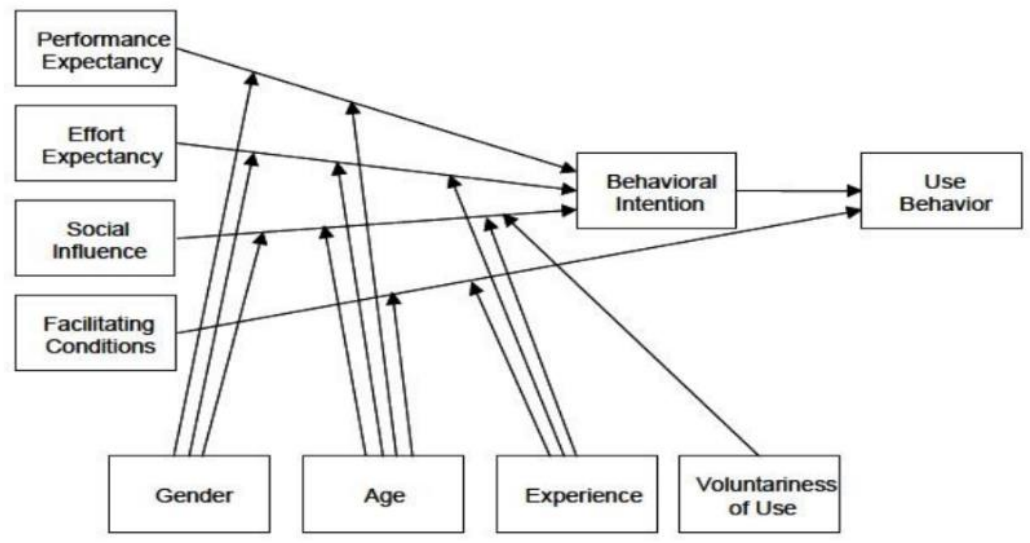

Gambar 1 Model UTAUT

\subsection{Hipotesis Penelitian}

UTAUT memiliki faktor-faktor yang berkaitan dengan niat perilaku penggunna untuk menggunakan teknologi maunpun dalam kontek teknologi organisasi. Dalam studi empiris penerimaan teknologi, UTAUT menjelaskan sekitar 70 persen niat perilaku pengguna dalam menggunakan teknologi dan sekita 50 persen dalam pengguna tekonologi (Vankatesh et.al 2012).Model ini merupakan kombinasi dari delapan model yang telah berhasil dikembangkan sebelumnya. Model UTAUT menunjukan bahwa niat untuk berperilaku (behavioral intention) dan perilaku untuk menggunakan suatu teknologi (use behavior) dipengaruhi oleh harapan akan kinerja (performance expectancy), harapan akan usaha (effort expectancy), pengaruh sosial (social influence), dan kondisi pendukung (facilitating conditions).

Pada penelitian ini memilki hipotesis penelitia yang menjadi jawaban sementara dari penelitian yang akan dilakukan, maka penulis membangun kerangka penelitian tentang analisis perilaku sistem Guru Pembelajar Online (GPO) pada guru Sekolah Menengah Pertama (SMP) di kota Palembang dengan variabel :

a. Ekspektasi Kerja (Performance Expectancy)

Ekspektasi kinerja (performance expectancy) didefinisikan sebagai tingkat dimana seorang individu meyakini bahwa dengan menggunakan sistem akan membantu dalam meningkatkan kinerjanya. Konsep ini menggambarkan manfaat sistem bagi pemakainya yang berkaitan dengan perceived usefulnees, motivasi ekstrinsik, job fit, keuntungan relatif (relative advantage) (Venkatesh et al. 2003). Konstruk Ekpektasi Kerja merupakan prdiktor yang kuat dari minat pemanfaatan sistem yang diatur secara wajib maupun sukarela.

Dalam penelitian Sedan dan Wijaya (2010), Handayani (2007), Sedan dan WIjaya (2009), Bendi dan Andayani (2013), Putra dan Ariyanti (2017) dan Beni dan Andayani (2013) mengumukakan jika Ekspektasi kinerja (performance expectancy) berpengaruh posistif terhadap niat untuk berperilaku (behavioral intention). Sebaliknya Jairak et.al., (2009) justru mengungkapkan sebaliknya.Berdasarkan uraianteoritis dan beberapa penelitian maka hipotesispertama dinyatakan.

H1 : Ekspektasi kinerja (performance expectancy)berpengaruh signifikan terhadap niat perilaku (behavioral intention) dalam menggunakan dan penggunaan GPO. 


\section{b. Effort Expectancy}

Ekspektasi usaha (effort expectancy) merupakan tingkat kemudahan penggunaan sistem yang akan dapat mengurangi upaya (tenaga dan waktu) individu dalam melakukan pekerjaannya. Tiga konstruk yang membentuk konsep ini adalah kemudahan penggunaan persepsian (perceived ease of use), kemudahan penggunaan (ease of use), dan kompleksitas (Venkatesh et al. 2003).

Venkatesh et.al (2012) menemukan bahwa effort expectancy memiliki pengaruh terhadap behavioral intention. Hal lain juga diungkapkan oleh Handayani (2007), Sedan dan Wijaya (2009), Bendi dan Andayani (2013), Putra dan Ariyanti (2017), sebaliknya Sedan dan Wijaya (2010) mengungkapkan sebaliknya bahwa effort expectancy tidak berpengaruh terhadap behavioral intention.

$\mathrm{H} 2$ : Ekspektasi usaha (effort expectancy) berpengaruh signifikan terhadap niat perilaku (behavioral intention) dalam menggunakan dan penggunaan GPO.

\section{c. Social Influence}

Faktor sosial (social influence) diartikan sebagai tingkat dimana seorang individu menganggap bahwa orang lain menyakinkan dirinya bahwa dia harus menggunakan sistem baru. Faktor sosial sebagai determinan langsung dari minat (behavioral intention) pemanfaatan sistem adalah direpresentasikan oleh konstruk-konstruk yang terkait yaitu norma subyektif, factor sosial dan image (Venkatesh et al. 2003).

Venkatesh et.al mengungkapkan bahwa social influence mempengaruhi behavioral intention. Hal itu juga diungkapkan oleh Jairak et.al., (2009), Sedana dan Wijaya (2009), Sedan dan Wijaya (2010), Handayani (2007), bahwa Faktor sosial (social influence) berpengaruh signifikan terhadap minat (behavioral intention), namun sebaliknya Bendi dan Andayani (2013), mengungkapkan jika Faktor sosial (social influence) tidak berpengaruh signifikan terhadap minat (behavioral intention).

H3 : Faktor sosial (social influence) berpengaruh signifikan terhadap niat perilaku (behavioral intention) dalam menggunakan dan penggunaan GPO.

\section{d. Facilitating Conditions}

Kondisi yang memfasilitasi (facilitating conditions) penggunaan sistem didefinisikan sebagai tingkat sejauh mana seseorang meyakini bahwa infrastruktur organisasi dan teknis yang ada mendukung penggunaan sistem (Venkatesh et.al 2003), Venkatesh juga mengungkapkan bahwa facilitating conditions tidak berpengaruh tehadap behavioral intention, namun mempengaruhi use behavior. Hasil ini mengakibatkan model model UTAUT yang dikembangkan hanya melihat pengaruh facilitating condition terhadap use behavior. Temuan serupa juga dipaparkan oleh Sedana dan Wijaya (2010), Sedana dan Wijaya (2009), Putra dan Ariyanti (2017) mengungkapkan jika Kondisi yang memfasilitasi (facilitating conditions) tidak berpengaruh postif terhadap use behavior. Sebaliknya Handayani (2007) mengungkapkan jika Kondisi yang memfasilitasi (facilitating conditions) berpengaruh postif terhadap use behavior. H4 : Faktor Kondisi yang memfasilitasi (facilitating conditions) berpengaruh signifikan terhadap perilaku pengguna (user behavioral) dalam menggunakan dan penggunaan GPO.

\section{e. Behavioral Intention}

Triandis (1980 dalam Handayani, 2007) mengemukakan bahwa perilaku seseorang merupakan ekspresi darin keinginan atau minat seseorang (intention), dimana keinginan tersebut dipengaruhi oleh faktor-faktor sosial, perasaan (affect), dan 
konsekuensi-konsekuensi yang dirasakan (perceived consequences). Davis et.al, (1989) mengemukakan bahwa adanya manfaat yang dirasakan oleh pemakai sistem akan meningkatkan minat mereka untuk menggunakan sistem. Sedangkan Thompson et.al, (1991) menyatakan bahwa keyakinan seseorang akan kegunaan sistem akan meningkatkan minat mereka dan pada akhirnya individu tersebut akan menggunakan sistem informasi dalam pekerjaannya. Venkatesh et.al, (2003), Handayani (2007), Sedana dan Wijaya (2009), Sedana dan Wijaya (2010) menyatakan bahwa terdapat adanya hubungan langsung dan signifikan antara niat perilaku (behavioral intention)terhadap penggunaan (user behavioral) sistem.

H5 : Faktor niat perilaku (behavioral intention) berpengaruh signifikan terhadap perilaku pengguna (user behavioral) dalam menggunakan dan penggunaan GPO.

Dari definisi variabel hipotesis diatas, berikut adalah gambar dari kerangka penelitian dari variabel-variabel penelitian yang akan digunakan dalam penelitian ini yang akan dianalisis menggunakan SEM dengan tools SmartPLS, yaitu :

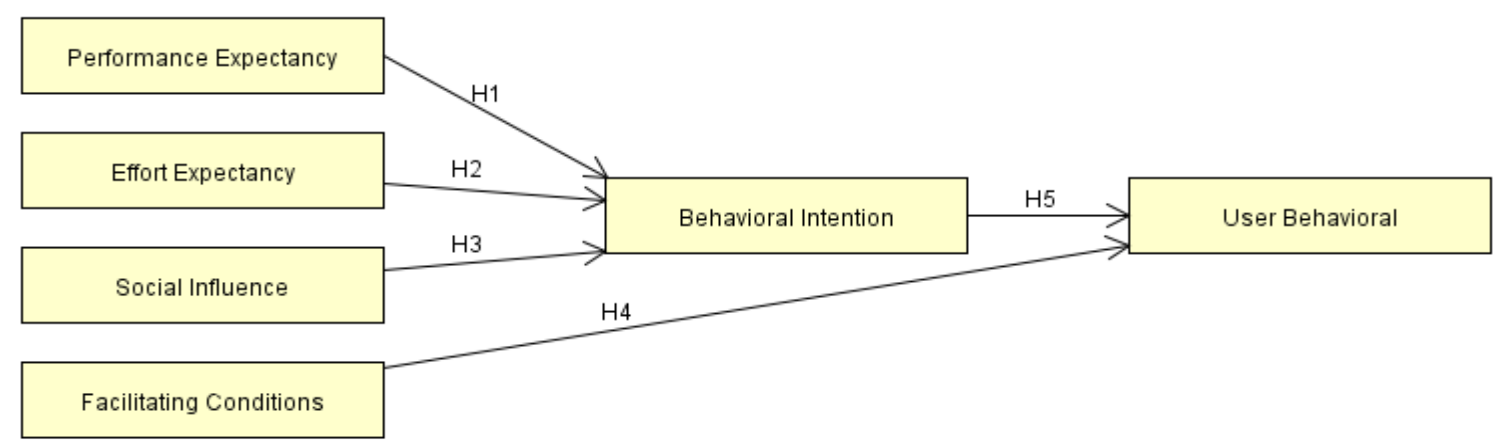

Gambar 2 Kerangka Penelitian

\section{METODOLOGI PENELITAN}

Dalam pengumpulan data pada penelitian ini menggunakan metode kuantitatif, berupa penyebaran kuisioner yang akan diskalakan menjadi angka dengan skala likert. Sedangkan penyajian data pada penelitian akan menggunakan metode kualitatif adalah pendekatan yang temuan-temuan penelitiannya tidak diperoleh memalui prosedur statistik atau bentuk perhitungan lainnya, prosedur ini menghasilkan temuan-temuan yang diperoleh dari data-data yang dikumpulkan dengan menggunakan beragam sarana yang disajikan berupa penjelasan dan pembahasan berdasrkan hasil statistic penelitian.Metode penelitian yang digunakan dalam penelitian ini adalah bersifat Asosiatif yaitu penelitian yang bertujuan untuk mengetahui hubungan dua variabel atau lebih. Dalam penelitian ini akan dilakukan penyebaran kuisioner yang digunakan untuk mengumpulkan data-data penelitian.Teknik analisis menggunakan Structural equation modeling atau model persamaan struktural adalah gabungan analisis faktor dan analisis jalur (path analysis) menjadi satu model statistic yang komprehensif. Analisis jalur sebagai cikal bakal persamaan structural bermula dari penelitian Sewll Wright (1918, 1921, 1934 dan 1960) dalam bidang biometrika. Wright mampu menunjukkan korelasi antara variabel dapat dihubungkan dengan parameter dari suatu model yang digambarkan dengan diagram jalur (path diagram). 


\subsection{Defisinisi Operasional Variabel}

Variabel dalam penelitian ini meliputi Ekspektasi kinerja (performance expectancy), Ekspektasi usaha (effort expectancy), Faktor sosial (social influence), Kondisi yang memfasilitasi (facilitating conditions), Minat pemanfaatan (behavioral intention), Perilaku Pengguna (Use Behavior). Berikut adalah uraian dari masing-masing variabel, yaitu :

Tabel 2 Indikator Variabel

\begin{tabular}{|c|c|c|c|c|}
\hline No & Variabel & Definisi operasional & Indikator & Sumber \\
\hline 1. & $\begin{array}{l}\text { Ekspektasi } \\
\text { kinerja } \\
\text { (performance } \\
\text { expectancy) }\end{array}$ & $\begin{array}{l}\text { Seseorang mempercayai } \\
\text { dengan menggunakan } \\
\text { teknologi informasi } \\
\text { tersebut akan membantu } \\
\text { orang tersebut untuk } \\
\text { memperoleh } \\
\text { keuntungan-keuntungan } \\
\text { kinerja pada pekerjaan }\end{array}$ & $\begin{array}{l}\begin{array}{l}\text { Persepsi } \\
\text { kegunaan } \\
\text { usefulness) } \\
\text { Motivasi } \\
\text { (perceived }\end{array} \\
\text { Kestrinsic motivation) } \\
\text { Kit) } \\
\text { Keuntungan pekerjaan (job } \\
\text { (relative advantage) } \\
\text { Ekspektasiekspektasi hasil } \\
\text { (outcome expectations) }\end{array}$ & 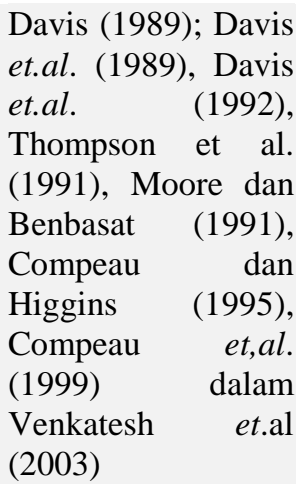 \\
\hline 2. & $\begin{array}{l}\text { Ekspektasi } \\
\text { usaha (effort } \\
\text { expectancy) }\end{array}$ & $\begin{array}{l}\text { Tingkat kemudahan } \\
\text { penggunaan teknologi } \\
\text { informasi yang akan } \\
\text { dapat mengurangi upaya } \\
\text { (tenaga dan waktu) } \\
\text { individu dalam } \\
\text { melakukan } \\
\text { pekerjaannya }\end{array}$ & $\begin{array}{l}\text { Ti sangat mudah dipahami } \\
\text { Ti mengerjakan dengan } \\
\text { mudah apa yang } \\
\text { diinginkan } \\
\text { penggunanya } \\
\text { Keterampilan pengguna } \\
\text { akan bertambah dengan } \\
\text { menggunakan ti } \\
\text { Ti tersebut sangat mudah } \\
\text { untuk dioperasikan }\end{array}$ & $\begin{array}{l}\text { Davis (1989); Davis } \\
\text { et.al. (1989), } \\
\text { Thompson et al. } \\
\text { (1991), Moore dan } \\
\text { Benbasat (1991), } \\
\text { dalam Venkatesh } \\
\text { et.al (2003) }\end{array}$ \\
\hline 3. & $\begin{array}{l}\text { Faktor sosial } \\
\text { (social } \\
\text { influence) }\end{array}$ & $\begin{array}{l}\text { Seorang individu } \\
\text { menganggap bahwa } \\
\text { orang lain menyakinkan } \\
\text { dirinya bahwa dia harus } \\
\text { menggunakan sistem } \\
\text { baru }\end{array}$ & $\begin{array}{l}\text { Ketaatan (compliance) } \\
\text { Internalisasi } \\
\text { (internalization) }\end{array}$ & 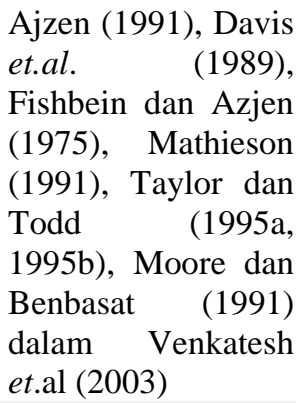 \\
\hline 4. & $\begin{array}{l}\text { Kondisi yang } \\
\text { memfasilitasi } \\
\text { (facilitating } \\
\text { conditions) }\end{array}$ & $\begin{array}{l}\text { Seseorang percaya } \\
\text { bahwa infrastruktur } \\
\text { organisasi dan teknis } \\
\text { ada untuk mendukung } \\
\text { penggunaan sistem }\end{array}$ & $\begin{array}{lr}\begin{array}{l}\text { Perasaan } \\
\text { (affect) }\end{array} & \begin{array}{r}\text { individual } \\
\text { terhadap }\end{array} \\
\text { penggunaan } & \text { komputer } \\
\text { personal } & \\
\text { Norma sosial } & \text { (social } \\
\text { norms) dalam tempat kerja } & \\
\text { yang memperhatikan } \\
\text { penggunaan } \\
\text { personal }\end{array}$ & $\begin{array}{l}\text { Ajzen (1991), } \\
\text { Taylor dan Todd } \\
\text { (1995a, 1995b), } \\
\text { Thompson et al. } \\
\text { (1991), Moore dan } \\
\text { Benbasat (1991) } \\
\text { dalam Venkatesh } \\
\text { et.al (2003) }\end{array}$ \\
\hline
\end{tabular}




\begin{tabular}{|c|c|c|c|c|}
\hline & & & $\begin{array}{lr}\text { komputer personal } \\
\text { Kondisi } & \text { yang } \\
\text { memfasilitasi } & \text { facilitating } \\
\text { conditions) } & \text { dalam } \\
\text { penggunaan } & \text { teknologi } \\
\text { informasi } & \end{array}$ & \\
\hline 5. & $\begin{array}{c}\text { Minat } \\
\text { pemanfaatan } \\
\text { (behavioral } \\
\text { intention) }\end{array}$ & $\begin{array}{l}\text { Keinginan atau niat } \\
\text { pemakai menggunakan } \\
\text { teknologi informasi } \\
\text { secara terus menerus } \\
\text { dengan asumsi bahwa } \\
\text { mereka mempunyai } \\
\text { akses terhadap } \\
\text { informasi }\end{array}$ & $\begin{array}{l}\text { Keinginan atau minat } \\
\text { seseorang (intention) } \\
\text { Perasaan (affect) } \\
\text { Konsekuensi konsekuensi } \\
\text { yang dirasakan (perceived } \\
\text { consequences) }\end{array}$ & $\begin{array}{l}\text { Sheppard et al. } \\
\text { (1988) dalam } \\
\text { Venkatesh } \text { et.al } \\
(2003)\end{array}$ \\
\hline 6. & $\begin{array}{l}\text { Perilaku } \\
\text { Pengguna } \\
\quad \text { (Use } \\
\text { Behavior) }\end{array}$ & $\begin{array}{c}\text { Frekuensi Pemakaian } \\
\text { dalam menggunakan } \\
\text { teknologi informasi }\end{array}$ & $\begin{array}{l}\text { Minat pengguna } \\
\text { Frekuensi penggunaan }\end{array}$ & 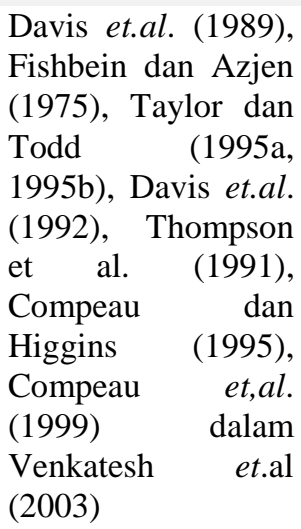 \\
\hline
\end{tabular}

\section{HASIL DAN PEMBAHASAN}

\subsection{Hasil}

\subsubsection{PengumpulanData}

Untuk mendapatkan suatu hasil penelitian ini, peneliti melakukan pengumpulan data berdasarkan dari penyebaran kuisioner. Kuisioner ini disebarkan kepada guru-guru di 15 Sekolah Menengah Pertama (SMP) Negeri di kota Palembang yang merupakan sampel dari penelitian yang menggunakan sistem Guru Pembelajar Online (GPO). Desain kuisioner pada penelitian bentuk yang sederhana yaitu terdiri dari 23 item pertanyaan.Dalam penelitian ini penelitian akan melakukan serangkaian tes atau pengujian terhadap data yang diproleh, alat yang digunakan adalah microsft excel untuk merekab data-data dari hasil penyebaran kuisioner dan telah diskala kedalam skala likert, SPSS digunakan sebagai alat untuk melakukan analisis data dan Smart PLS digunakan untuk mengindentifikasi dan menganalisis hubungan antara variabel-variabel penelitian.

penyebaran kuisioner peneliti menyebarkan sebanyak 300 kuisioner, hal itu dilakukan karena mengantisipasi jika dalam penyebaran kuisioner terjadi data yang tidak jelas, rusak atau tidak dapat dibaca, selain itu peneliti meminimalisir jika kuisioner yang disebarkan tidak sesuai dengan harapan atau target yang ingin diinginkan, contoh peneliti menyebarkan sebanyak 50 kuisioner belum tentu kusioner akan kembali dengan jumlah sama atau tidak sebanyak yang kita sebarkan.

Dari 300 penyebaran kuisioner yang dilakukan, kuisioner yang kembali 253, namun data yang dapat diolah sebanyak 250, dari data kuisioner yang dikumpulkan telah memenuhi standar sampel yang diharuskan untuk penelitian ini, sehingga data bisa dilanjutkan kepengolahan selanjutnya. 


\subsubsection{Persiapan Data}

Persiatan data atau data screening merupaka salah satu proses persiapan data untuk analisis. Tujuan utama dari data screening adalah khususnya untuk menghilangkan data-data yang hilang (missing value) ataupun data-data yang dianggap tidak normal.Pada penelitian ini tentang perilaku pengguna terhadap sistem guru pembelajar online (GPO) yang terdiri dari 6 variabel yaitu performance expectancy, effort expectancy, social influence, facilitating conditions, behavioral intention, use behavior.Berdasarkan analisis yang dilakukan menunjukkan dari 6 variabel penelitia dengan 248 data kuisioner tidak memiliki atau terdapat data yang hilang, sehingga 248 data kuisioner memiliki data yang lengkap.Langkah persiapan data berikutnya adalah melakukan pengecekapan pada tanggapan responden pada tiap-tiap peranyaan dalam kuisioner. Hasilnya menunjukkan terdapat 2 data yang tidak memenuhi yaitu dibawah 0,5, dari 248 data kuisioner terdapat 2 data yang tidak memenuhi dan harus dihapus.

Setelah melakukan persapan data dengan missing data dan tanggapan responden, maka selanjutnya dilakukan pengujian normalitas, Hair et al (2010) mengemukakan normalitas mengacu pada bentuk distribusi data dan karateristik untuk satu variabel metrik tunggal yang memenuhi distribusi nirmal. Skewnee dan kurtosisi adalah dua mekanisme yang digunakan untuk memeriksa apakah data terdistribusi secara normal atau tidak, sementara skewness digunakan untuk menggambarkan keseimbangan distribusi, kurtosis digunakan untuk memeriksa rata-rata distribusi (Tabachnick dan Fidell, 2001, Hair et al., 2010). Kline (2010, 63) menyarankan nilai antara -3 dan +3 untuk skewness untuk mengkategorikan pendistribusian data normal, Kline menyatakan nilai 8,0 untuk kurtosis menunjukkan adanya masalah.Tidak seperti AMOS atau LISREL, PLS tidak memerlukan data terdistribusi normal untuk memberikan rekomendasi yang menonjol (Esposito Vinzi et al., 2010, Chin, 2010)

\subsubsection{Adequacy}

Setelah melakukan pengumpulan data dan persiapan data selanjutnya adalah adequacy sampel atau kecukupan yang memeriksa jumlah sampel yang cukup besar untuk memberikan ketepatan hasil tes yang dibutuhkan dan untuk mendukung generalisasi (Syamsuar, 2015). Menurit Barclay et al (1995), ukuran sampel harus lebih dari sepuluh kali jumlah item dalam konstruk yang paling kompleks. Pada model penelitian ini memiliki 6 konstruk/variabel penelitian, Barclay menyarankan ukuran sampel yang harus dimiliki minimal 60 untuk konstruk pada penelitian ini. Dalam penelitian ini memiliki 246 data responden yang valid sehingga ukuran sampel melebihi ukuran sampel yang ditentukan.Menurut Hair et al (2010) menyarankan untuk menguji kecukupan ukuran menggunakan Ukuran Kaiser-Meyer-Olkin dari Kecukupan Sampling (KMOMSA) dan Bartlett's Test of Sphericity (BToS) untuk memeriksa kesesuaian data. Nilai KMO dianggap mencukupi jika lebih dari 0,5 maka dapat diterima. Nilai Bartlett Test of Spehricity memenuhi persyaratan signifikansi di bawah 0,05 (5\%), jika nilai BToS dibawah 0,05 maka sampel memenuhi kecukupan yang siqnifikan.Berikut adalah hasil pengujian KMOMSA dan BToS dari setiap variabel :

Table 3 :KMOMSA dan BToS

\begin{tabular}{lrr}
\hline \multicolumn{2}{c}{ KMO and Bartlett's Test } \\
\hline Kaiser-Meyer-Olkin Measure of Sampling Adequacy. & .806 \\
\hline Bartlett's Test of Sphericity & Approx. Chi-Square & 3678.690 \\
& & 253 \\
& df & .000 \\
\hline
\end{tabular}




\subsubsection{Deskripsi Responden}

Hasil dari penyebaran kuisioner didapatkan data dari setiap resonden yaitu guru pengguna aplikasi GPO dan didapatkan kriteria dari reponden penelitian yaitu berdasarkan umur responden, jenis kelamin, pendidikan terakhir, pengalaman kerja dan lama penggunaan komputer perhari, data setiap karakter penelitian dapat dilihat sebagai berikut :

Tabel 4 Deskripsi Profil Analisis Responden

\begin{tabular}{|c|c|c|c|}
\hline \multicolumn{2}{|l|}{ Umur } & \multicolumn{2}{|c|}{ Pendidikan terakhir } \\
\hline 25-30 Tahun & $16,5 \%$ & S1 & $89,5 \%$ \\
\hline 31-45 Tahun & $36,7 \%$ & $\mathrm{~S} 2$ & $7,3 \%$ \\
\hline 46 Tahun & $46,82 \%$ & S3 & $0 \%$ \\
\hline \multicolumn{2}{|l|}{ Jenis Kelamin } & Diploma & $3,2 \%$ \\
\hline \multirow{2}{*}{$\begin{array}{l}\text { Laki-laki } \\
\text { Perempuan }\end{array}$} & $18,2 \%$ & \multicolumn{2}{|c|}{ Pengalaman Kerja } \\
\hline & $81,8 \%$ & \multirow{5}{*}{$\begin{array}{l}<5 \text { Tahun } \\
6-10 \text { Tahun } \\
\text { 11-20 Tahun } \\
>21 \text { Tahun }\end{array}$} & \multirow{2}{*}{$\begin{array}{l}6,4 \& \\
32,2 \%\end{array}$} \\
\hline \multicolumn{2}{|c|}{ Lama menggunakan computer } & & \\
\hline <3 Jam & $48 \%$ & & $33,9 \%$ \\
\hline 4-6 Jam & $32,7 \%$ & & $19,3 \%$ \\
\hline$>7$ Jam & $19,3 \%$ & & \\
\hline
\end{tabular}

\subsubsection{Measurement Model Validity}

Setelah melakukan pengolahan data awal dengan penginputan data dan penyaringan data. Tahap selanjutnya yaitu membangun model, evaluasi dalam model PLS terdiri dari dua tahap yaitu evalusi outer model atau model pengukuran (measurement model) dan evaluasi inner model atau model structural (structural measurement).

\subsubsection{Indikator Reliabilitas}

Meskipun pertanyaan telah didefinisikan secara hati-hati dan jelas selama pengembangan kuesioner itu sendiri, pengujian reliabilitas dianjurkan untuk meningkatkan akurasi pengukuran dan untuk memastikan bahwa data dapat dipercaya (Straub et al., 2004). Selain itu, Hair et al. (2010) berpendapat bahwa tujuan indikator reliabilitas adalah Uji reliabilitas ialah pengujian untuk mengukur kuesioner yang merupakan indikator dari variabel. Suatu kuesioner dapat dikatakan reliabel atau handal jika jawaban terhadap pertanyaan menghasilkan jawaban yangkonsisten atau stabil dari waktu ke waktu.

Metode pendugaan parameter (estimasi) di dalam penelitian ini menggunakan PLS Algorithm pada software smartPLS 3. Ketentuan untuk menguji unidimensionalitas dari masing-masing konstruk dengan melihat convergent validity dari masing-masing indikator konstruk. Convergent validity mengukur besarnya korelai antar konstruk dengan variabel laten. Dalam evaluasi convergent validity dari pemeriksaan individual item reliability, dapat dilihat dari nilai standardized loading factor.Nilai loading factor $\geq 0,7$ dikatakan ideal, artinya indicator tersebut valid konstruk yang dibentuknya. Dalam pengalaman empiris penelitian nilai loading factor $\geq 0,5$ masih bisa diterima. Bahkan sebagian ahli mentolelir angka 0,4. Dengan demikia nilai loading factor $\leq 0,4$ harus dikeluarkan dari model (di-drop) (Haryono, 2017). Hasil analisis dapat dilihat pada tabel dibawah ini : 
Table 5Cross Loading Assessment

Konstruk

\begin{tabular}{|c|c|c|c|c|c|c|c|c|}
\hline \multirow{2}{*}{ Indikator } & \multicolumn{6}{|c|}{ Konstruk } & \multirow{2}{*}{$\begin{array}{c}\text { Distance to } \\
\text { the closest } \\
\text { loading }\end{array}$} & \multirow{2}{*}{ Remake } \\
\hline & BI & $\mathbf{E E}$ & FC & PE & SC & UB & & \\
\hline BI1 & 0.85 & 0.434 & 0.434 & 0.443 & 0.334 & -0.012 & 0.407 & \\
\hline BI2 & 0.892 & 0.426 & 0.435 & 0.431 & 0.287 & -0.057 & 0.457 & \\
\hline BI3 & 0.885 & 0.461 & 0.432 & 0.466 & 0.202 & -0.044 & 0.419 & \\
\hline BI4 & 0.812 & 0.435 & 0.463 & 0.465 & 0.289 & 0.018 & 0.347 & \\
\hline EE1 & 0.341 & 0.822 & 0.377 & 0.519 & 0.439 & -0.137 & 0.303 & \\
\hline EE2 & -0.291 & -0.287 & -0.207 & -0.092 & 0.016 & 0.087 & -0.374 & $\begin{array}{c}\text { Cross } \\
\text { Loading }\end{array}$ \\
\hline EE3 & 0.071 & 0.214 & 0.002 & 0.277 & 0.164 & 0.069 & -0.063 & $\begin{array}{c}\text { Cross } \\
\text { Loading }\end{array}$ \\
\hline EE4 & 0.435 & 0.907 & 0.474 & 0.584 & 0.386 & -0.135 & 0.323 & \\
\hline FC1 & 0.426 & 0.454 & 0.766 & 0.333 & 0.242 & -0.171 & 0.312 & \\
\hline FC2 & 0.521 & 0.403 & 0.861 & 0.399 & 0.343 & -0.204 & 0.340 & \\
\hline FC3 & 0.320 & 0.305 & 0.686 & 0.241 & 0.153 & -0.160 & 0.366 & $>0,7$ \\
\hline FC4 & 0.285 & 0.413 & 0.756 & 0.327 & 0.232 & -0.161 & 0.343 & \\
\hline PE1 & 0.178 & 0.283 & 0.099 & 0.577 & 0.101 & 0.066 & 0.294 & $>0.7$ \\
\hline PE2 & 0.521 & 0.588 & 0.395 & 0.923 & 0.36 & -0.003 & 0.335 & \\
\hline PE3 & 0.518 & 0.621 & 0.500 & 0.900 & 0.382 & -0.106 & 0.279 & \\
\hline PE4 & 0.163 & 0.150 & 0.019 & 0.543 & 0.146 & 0.018 & 0.380 & $>0.7$ \\
\hline SI1 & 0.252 & 0.383 & 0.300 & 0.358 & 0.946 & -0.035 & 0.563 & \\
\hline SI2 & 0.224 & 0.315 & 0.266 & 0.265 & 0.705 & -0.024 & 0.390 & \\
\hline SI3 & -0.134 & 0.069 & 0.117 & 0.086 & 0.216 & 0.090 & 0.099 & $\begin{array}{c}\text { Cross } \\
\text { Loading }\end{array}$ \\
\hline SI4 & 0.256 & 0.383 & 0.298 & 0.353 & 0.944 & -0.038 & 0.561 & \\
\hline UB1 & -0.026 & -0.158 & -0.227 & -0.055 & -0.067 & 0.934 & 0.960 & \\
\hline UB2 & -0.017 & -0.150 & -0.188 & -0.050 & -0.061 & 0.911 & 0.928 & \\
\hline UB3 & -0.032 & -0.136 & -0.201 & 0.008 & -0.032 & 0.882 & 0.874 & \\
\hline
\end{tabular}

Dari tabel di atas yang menunjukkan hasil analisis dari konstruk, dari data diats dapat kita lihat terdapat beberapa konstruk berada dibawah nilai yang diinginkan yaitu sebesar 0,7. Terdapat 6 indikator yang dihapus karena dari 6 indikator tersebut tidak memenuhi nilai dari loading factor. Berikut adalah indicator yang harus dihapus, yang dapat dilihat pada tabel dibawah ini :

Tabel 6 Analisis Faktor

\begin{tabular}{|c|c|c|}
\hline Konstruk & Item yang Dihapus & Alasan \\
\hline PE1 & $\begin{array}{l}\text { PE1 - Penggunaan Sistem Guru Pembelajar Online } \\
\text { (GPO) meningkatkan standar kualitas guru sebagai } \\
\text { evaluasi peningkatan kinerja saya }\end{array}$ & Loading $<0,7$ \\
\hline PE4 & $\begin{array}{l}\text { PE2 - Menggunkan Sistem Guru Pembelajar Online } \\
\text { (GPO) meningkatkan produktifitas saya }\end{array}$ & Loading $<0,7$ \\
\hline EE2 & $\begin{array}{l}\text { EE2 - Membutuhkan waktu yang cukup saat saya } \\
\text { menggunakan Sistem Guru Pembelajar Online (GPO) }\end{array}$ & $\begin{array}{l}\text { Faktor lain : memperbaiki } \\
\text { loading } \\
\text { Cross loading }>0,2\end{array}$ \\
\hline EE3 & $\begin{array}{l}\text { EE3 - Keterampilan saya akan bertambah dengan } \\
\text { menggunakan Sistem Guru Pembelajar Online (GPO) }\end{array}$ & $\begin{array}{l}\text { Faktor lain : memperbaiki } \\
\text { loading } \\
\text { Cross loading }>0,2\end{array}$ \\
\hline SI3 & $\begin{array}{l}\text { SI3 - Rekan kerja/guru saya berpengaruh dalam } \\
\text { menggunakan Sistem Guru Pembelajar Online (GPO) }\end{array}$ & $\begin{array}{l}\text { Faktor lain : memperbaiki } \\
\text { loading Cross loading }>0,2\end{array}$ \\
\hline
\end{tabular}


FC3

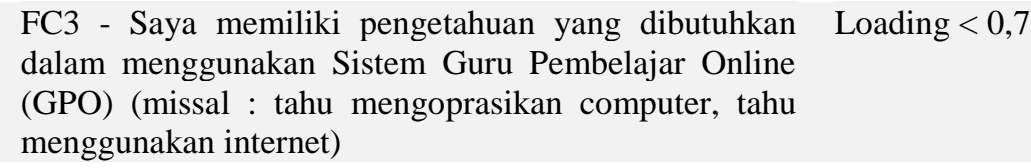

Dari tabel 6 menunjukkan beberapa indicator penelitian yang harus didrop/dihapus karena tidak memenuhi kriteria yang ditentukan. Setelah melakukan analisis terhadap indicator maka tahap selanjutnya adalah convergent validityyang menilai apakah indikator konstruk konvergen tertentu atau memiliki jumlah varians yang tinggi (Hair et al., 2010; Straub et al., 2004). Untuk memeriksa validitas konvergen, untuk mengetahui convergent validity, Variance Extracted (AVE) untuk memeriksa konstruk yang sering digunakan. Nilai EVA untuk convergent validity harus > 0,5 (Mustafa dan WIjaya (2012:16), Ghozali (2014:43).Convergent validity dari measurement model dengan indikator refleksif dapat dilihat dari korelasi antara skor item/indikator dengan konstruknya (loading factor) yang dapat dilihat dari output outer loadings.Output outer loadings dari hasil estimasi PLS Algorithm dapat dilihat pada tabel 7.

\subsubsection{Evaluation Of Reliability}

Setelah mengevaluasi individual item reliability melalui standardized loading factor langkah selanjutnya kita melihat internal consistency reliability dari nilai cronbach's alpha dan composite reliability (CR). composite reliability (CR) lebih baik dalam pengukuran internal consistency dibandingkan cronbach's alpha dalam SEM kerena CR mengasumsikan kesamaan boot dari setiap indicator. Interpensi composite reliability (CR) sama dengan cronbach's alpha. Nilai batas $\geq 0,7$ dapat diterima dan nilai $\geq 0,8$ sangat memuaskan. Tingkat reliabilitas yang diterima secara umum $\geq 0,70$ sedangkan reliabilitas $\leq 0,70$ dapat diterima untuk penelitian yang masih bersifat eksploratori. Ukuran lain dari convergent validity adalah nilai average variance extracted (AVE). nilai AVE menggambarkan besarnya varian atau keragaman variabel manifest yang dapat dimilii oleh konstruk laten. Dengan demikina, semakin besar varian atau keragaman variabel manifest yang dapat dikandung oleh konstruk laten, maka semakin besar representative variabel manifest terhadap konstruk latennya (Haryono, 2017).

Convergent validity dari measurement model dengan indikator refleksif dapat dilihat dari korelasi antara skor item/indikator dengan konstruknya (loading factor) yang dapat dilihat dari output outer loadings. Output outer loadings dari hasil estimasi PLS Algorithmyang dapat dilihat pada tabel 7.

\begin{tabular}{|c|c|c|c|c|c|c|}
\hline $\begin{array}{c}\text { Variabel } \\
\text { Name }\end{array}$ & $\begin{array}{c}\text { Indicator } \\
\text { Name }\end{array}$ & $\begin{array}{c}\text { Loading } \\
\text { Factor }\end{array}$ & AVE & Communality & $\begin{array}{l}\text { Cronbach } \\
\text { Alpha }\end{array}$ & $\begin{array}{c}\text { Composite } \\
\text { Reability }\end{array}$ \\
\hline \multirow[t]{4}{*}{$\mathrm{BI}$} & BI1 & 0.850 & 0.740 & 0.740 & 0.882 & 0.919 \\
\hline & BI2 & 0.892 & & & & \\
\hline & BI3 & 0.883 & & & & \\
\hline & BI4 & 0.813 & & & & \\
\hline \multirow[t]{2}{*}{$\mathrm{EE}$} & EE1 & 0.908 & 0.858 & 0.858 & 0.836 & 0.923 \\
\hline & EE4 & 0.944 & & & & \\
\hline \multirow[t]{3}{*}{ FC } & FC1 & 0.848 & 0.682 & 0.682 & 0.766 & 0.865 \\
\hline & $\mathrm{FC} 2$ & 0.868 & & & & \\
\hline & FC4 & 0.757 & & & & \\
\hline \multirow[t]{2}{*}{ PE } & PE2 & 0.933 & 0.870 & 0.870 & 0.851 & 0.930 \\
\hline & PE3 & 0.932 & & & & \\
\hline
\end{tabular}




$\begin{array}{lllllll}\text { SI } & \text { SI1 } & 0.955 & 0.791 & 0.791 & 0.861 & 0.918 \\ & \text { SI2 } & 0.745 & & & & \\ & \text { SI4 } & 0.952 & & & & \\ \text { UB } & \text { UB1 } & 0.933 & 0.826 & 0.826 & 0.895 & 0.934 \\ & \text { UB2 } & 0.919 & & & & \end{array}$

Tabel 7 menunjukkan bahwa composite reability dan cronbach alpha untuk semua konstruksi memenuhi kreteria nilai yang di inginkan dan berada di atas nilai yang disarankan. Nilai composite reliability masing-masing konstruk sudah di atas 0,70 . Jadi, dapat disimpulkan bahwa masing-masing konstruk sudah memiliki reliabilitas yang baik.

\subsubsection{Evaluation Of Discriminant Validity}

Discriminant Validity digunakan untuk menguji apakah masing-masing faktor terkait dengan faktor lain (Hair et al., 2010). Gefen dan Straub (2005) menjelaskan bahwa dua prose yang digunakan untuk memeriksa validitasnya: (1) memeriksa cross-loading dan (2) menilai akar kuadrat AVE untuk melakukan Analisis Kriteria Forner-Larker (Wong, 2013). Nilai akar kuadrat dari EVA lebih besar dari nilai Korelasi antar variabel laten (Mustafa dan WIjaya, 2012:16, Ghozali 2014:43 dalam Haryano 2017:373).Discriminant Validity dari indikator refleksif dapat dilihat pada cross loading antara indikator dengan konstruknya. Output cross loading hasil dari outputPLS Algorithm dapat dilihat pada Tabel berikut :

\begin{tabular}{|c|c|c|c|c|c|c|}
\hline & $\begin{array}{l}\text { Behavioral } \\
\text { Intention }\end{array}$ & $\begin{array}{l}\text { Effort } \\
\text { Expectancy }\end{array}$ & $\begin{array}{l}\text { Facilitating } \\
\text { Condition }\end{array}$ & $\begin{array}{l}\text { Performance } \\
\text { Expectancy }\end{array}$ & $\begin{array}{l}\text { Social } \\
\text { Influence }\end{array}$ & $\begin{array}{l}\text { User } \\
\text { Behavior }\end{array}$ \\
\hline BI & 0.860 & & & & & \\
\hline $\mathbf{E E}$ & 0.424 & 0.926 & & & & \\
\hline FC & 0.507 & 0.456 & 0.826 & & & \\
\hline PE & 0.557 & 0.614 & 0.494 & 0.933 & & \\
\hline SI & 0.276 & 0.429 & 0.335 & 0.383 & 0.890 & \\
\hline UB & -0.027 & -0.147 & -0.218 & -0.058 & -0.036 & 0.909 \\
\hline
\end{tabular}

Berdasarkan tabel output cross loadings dapat dilihat bahwa korelasi masing-masing indikator dengan konstruknya lebih tinggi dari pada dengan konstruk lain. Hal ini menunjukan bahwa konstruk laten memprediksi indikator pada bloknya sendiri lebih baik dibandingkan dengan indikator di blok lain.

\subsubsection{Structural Model}

Setelah mengevaluasi masurement model konstrak/variabel dengan melakukan pengujian validitas dan reliabilitas, tahap selanjutnya adalah membuat model struktur dengan tools SmartPLS 3 dengan Indikator dari masing-masing konstruk yaitu konstruk FE (Ferformance Expectancy), EE (Effort Expectantion), SI (Social Influece), FC (Facilitating Condition), BI (Behavioral Intention) dan UB (Use Behavior). Dalam structural model hipotesis diuji melali signifikan dari (1) path coefficients, (2) t-statistik, dan (3) r-squered value.

\subsubsection{Path Coefficients}

Path coefficients menggambarkan hubungan (Hair et al, 2010) dan signifikansi dari hubungan hipotesis (Hair et al, 2014) antar konstruk. Semakin tinggi path coefficients maka semakin kuat efek dari variabel laten independen terhadap variabel dipenden (Hair et al., 2014). Model memiliki kekuatan prediksi yang signifikan pada nilai 0,20 atau lebih (Lowry \& Gaskin, 
2014). Signifikansinya dapat dilihat pada t test atau C.R (critica ratio) yang diperoleh dari proses bootstrapping atau resampling model. Signifikansi t-value untuk path coefficients dan nilai p untuk mengukur tingkat signifikan. Hair et al., (2014) mengungkapkan nilai yang dibutuhkan path coefficients adalah 1.65 untuk nilai t-statistik, tingkat signifikan untuk nilai $\mathrm{p}$ masing-masing 0.10.nilai dari path coefficients dapat dlihat pada tabel 9 berikut ini :

\begin{tabular}{lccl} 
& \multicolumn{3}{c}{ Tabel 9 Path Coefficients } \\
& Original Sample (O) & T Statistics $(\mid \mathbf{O} / \mathbf{S T D E V})$ & Keterangan \\
PE -> BI & 0.112 & 6.560 & Diterima \\
EE -> BI & 0.118 & 1.805 & Diterima \\
SI -> BI & -0.275 & 0.717 & Ditolak \\
FC -> UB & 0.467 & 4.171 & Diterima \\
BI -> UB & 0.046 & 1.507 & Ditolak
\end{tabular}

Pada tabel diatas menunjukkan jika uji hipotesis terhadap 5 konstruk dalam penelitian ini terdapat 3 konstruk yang memenuhi nilai 1,65 dan diterima, sedangkan terdapat dua konstruk penelitian yang tidak memenuhi nilai yaitu 1.65 dan ditolah.

\subsubsection{R-Square Value}

Struktural model pada PLS-SEM ditentukan dengan menilai kekuatan penjelas dari struktural model (Gefen et al., 2000; Hair et al., 2006) dan path coefficients (Hair et al., 2010; Henseler et al., 2009; Tabachnick \& Fidell, 2001 dalam Syamsuar 2015). Pengujian jalur sebelumnya menunjukkan bahwa empat variabel independen performance expectancy dan effort expectancy berpengaruh pada variabel dependenbehavioral intention, untuk facilitating condition dan behavioral intention berpengaruh signifikan terhadap variabel dependen user behavior, sedangkan satu variabel yaitusocial influence tidak berpengaruh pada behavioral intention. Seperti yang disarankan oleh Hair et al. (2014), penelitian saat ini menilai kekuatan penjelasan model dengan menghitung korelasi multiple kuadrat $R^{2}$.

Menurut Hair et al. (2010) dan Ghozali (2011 dalam Haryono, 2017) tingkat $R^{2}$ penting dalam mengevaluasi model struktural. Chin (2010) merekomendasikan bahwa nilai $R^{2}$ untuk variabel laten endogen dalam model bagian dalam digambarkan sebagai baik, sedang atau lemah. Untuk nilai $R^{2}$ 0,67 untuk mengidentifikasi model baik, 0,33 untuk mengidentifikasi model sedang atau cukup baik atau 0,19 untuk mengidentifikasi model lemah. Nilai $R$-square masing-masing konstruk endogen dari estimasi model dapat dilihat pada Tabel berikut :

\begin{tabular}{lc}
\multicolumn{2}{c}{ Tabel 10 Output $R$-square } \\
\multicolumn{2}{c}{ R Square } \\
\hline Behavioral Intention & 0.379 \\
User Behavior & 0.057
\end{tabular}

Model akhir dan ringkasan pengujian tentang hasil analisis perilaku pengguna terhadap sistem guru pembelajar online (GPO) pada sekolah menengah pertama (SMP) di kota Pelmbang, setalah melalui proses pengolahan data dengan meakukan pembesihan data sebagai tahapan pertama, tahap selanjutnya mengolah dengan PLS dengan membuat measurement model dan structural model dengan menguji data, berikut adalah hasil dari model penelitian disajikan sebagai berikut : 


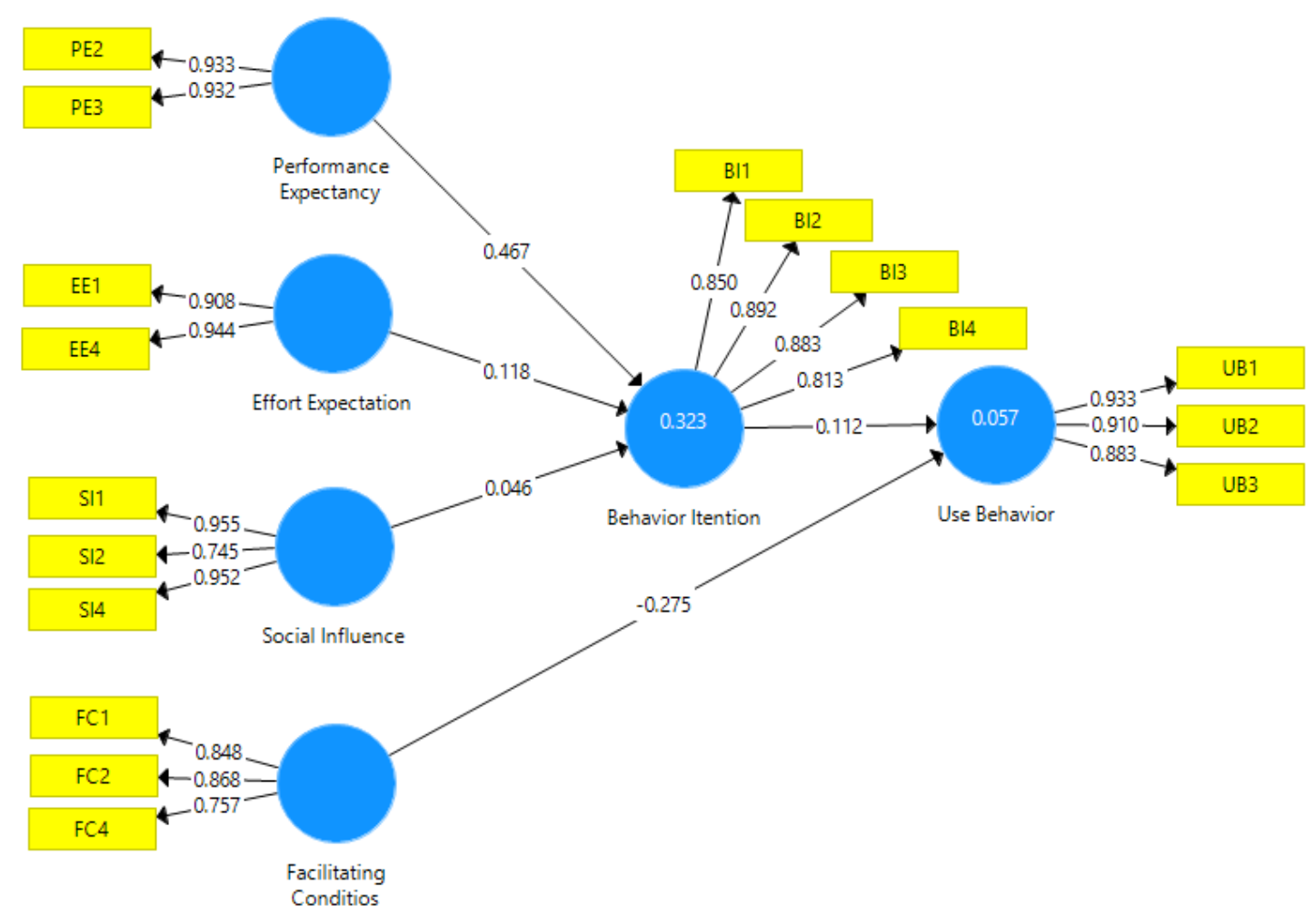

Gambar 3 Estimasi Model

\subsection{PEMBAHASAN}

\subsubsection{Pengaruh Perilaku Pengguna Terhadap Penerimaan Sistem Guru Pembelajar Online (GPO)}

Dari hasil pengujian yang telah dilakukan menggunakan tools SPSS dan smartPLS sebagai alat untuk mengolah dengan melakukan pembersihan data dengan proses data screening, dari pengolahn 248 dari data penyebaran kuisioner didapatkan 246 kuisioner yang dapat diolah dan dilanjutkan ketahap selanjutnya yaitu menganalisis data. Hasil dari pengolahan yang dilakukan mendapatkan pengujian terhadap konstruk penelitian, dari hasil analisis data diperoleh hasil pengujian reliabilitas yang ditunjukkan dengan nilai loading factor pada cross loading, dari 23 indikator dengan 6 variabel penelitian terdapat 6 indikator yang harus didrop karena Nilai loading factor $\geq 0,7$ dikatakan ideal, artinya indicator tersebut valid konstruk yang dibentuknya (Haryono, 2017).

Setelah melakukan pengujian reliabilitas dilakukan juga pengujian kondtruk validitas dengan convergent validity dengan melihat korelasi antara skor item/indikator dengan konstruknya (loading factor) yang dapat dilihat dari output outer loadings. Dari semua nilai loading factor setiap indikator sudah di atas 0,50 jadi masing-masing konstruk sudah memenuhi convergent validity (Mustafa dan WIjaya (2012:16), Ghozali (2014:43), Haryano (2017:373). Dari semua pengujian data yang dilakukan dapat dilakukan analisis data, dari analisis data dapat diporoleh hasil dari dan konstruk sebagai berikut : 
a. Analisis Mengenai Pengaruh Antara Variabel Performance Expectancy (PE) dengan Behavioral Intention

Dari hasil uji hipotesis variabel performance expectancy berpengaruh pada behavioral intention. Hasil menunjukkan nilai t-statistik $6.560 \geq 1,65$ sehingga dapat disimpulkan terdapat pengaruh yang signifikan terhadap niat perilaku (behavioral intention) dari pengguna GPO. Hal ini sama seperti yang disampaikkan dalam penelitian Handayani (2007), Sedan dan WIjaya (2009). Pada konstruk performance expectancy memiliki 2 indikator yang harus didrop karena nilai loading factor, performance expectancy (PE) yang harus didrop adalah item PE1 yang memiliki nilai 0,592 dengan pertanyaan Penggunaan Sistem Guru Pembelajar Online (GPO) meningkatkan standar kualitas guru sebagai evaluasi peningkatan kinerja saya, hal ini dipengaruhi oleh standar kualitas guru untuk meningkatkan kinerja guru tidak hanya dengan sistem GPO, banyak faktor yang digunakan untuk meningkatkan kualitas guru baik itu dari adanya pelatihan-pelatihan guru dan pembinaan-pembinaan yang sering diadakan oleh Kementerian Pendidikan dan Kebudayaan Direktorat Jenderal Guru dan Tenaga Kependidikan. Untuk Indikator PE4 memilki nilai 0,588 dengan pertanyaan Secara umum pihak sekolah mendukung saya menggunakan Sistem Guru Pembelajar Online (GPO) dalam peningkatan kualitas guru (missal : menyediakan computer, akses internet), hal itu dipengaruhi oleh pemakai GPO itu sendiri yaitu guru yang belum begitu memiliki minat dalam menggunakan GPO, sehingga fasislitas yang disediakan oleh kepala sekolah kurang dimanfaatkan oleh guru dalam mengakses sistem GPO

b. Analisis Mengenai Pengaruh Antara Variabel Effort Expectancy(EE) dengan Behavioral Intention

Variabel effort expectation (EE) dengan jumlah 4 item atau pertanyaan. Pada variabel effort expectancy berkontribusi pada behavioral intention. Hasil menunjukkan nilai t-statistik 1.805 $\geq 1,65$ sehingga kesimpulan dari variabel effort expectancy berpengaruh terhadap niat perilaku (behavioral intention) dari pengguna GPO. Hasil penelitian ini sama seperti yang dikemukakan oleh Venkatesh et.al (2012), Handayani (2007), Sedan dan Wijaya (2009), Bendi dan Andayani (2013). Pada akonstruk effort expectancy terdapat indikator yang harus didrop yaitu EE2 yang memiliki nilai -0,143 dengan pertanyaan membutuhkan waktu yang cukup saat saya menggunakan sistem guru pembelajar online (GPO) hal itu dipengaruhi oleh waktu yang dibutuhkan dalam menggunakan sistem (GPO) membutuhkan waktu yang cukup bagi guru dalam melakukan evaluasi atau mengerjakan tugas, selain itu guru juga membutuhkan waktu untuk memahami sistem GPO itu sendiri baik dari segi tampilan dan prosedur yang ada didalam sistem GPO. Untuk indikator EE3 juga memiliki nilai kecil yang harus didrop yaitu 0,361 dengan pertanyaan keterampilan saya akan bertambah dengan menggunakan sistem guru pembelajar online (GPO) hal itu dipengaruhi oleh untuk meningkatkan ketrampilan guru tidak hanya dengan menggunakan sistem GPO, namun hal itu didasari oleh personalia dari masing-masing guru.

c. Analisis Mengenai Pengaruh Antara Variabel Social Influence(SI) dengan Behavioral Intention

Pada variabel variabel social influence tidak berkontribusi pada behavioral intention. Hasil menunjukkan nilai t-statistik $0.717 \leq 1,65$ sehingga kesimpulan dari variabel effort expectancy tidak berpengaruh terhadap niat perilaku (behavioral intention) dari pengguna GPO. Hal ini sama seperti yang dikemukanan oleh Sedan dan Wijaya (2010) dan Bendi dan Andayani (2013). Dalam analisis konstruk penelitian variabel social influence juga mememiliki indicator yang harus didrop yaitu SI3 dengan nilai 0,360 dengan pertanyaan rekan kerja/guru saya berpengaruh dalam menggunakan sistem guru pembelajar online 
(GPO) hal ini dipengaruhi oleh Rekan kerja tidak begitu berpengaruh dengan pengguna dalam menggunakan sistem GPO karena semua Guru Sekolah Menengah Pertama (SMP) diharuskan menggunakan GPO jika nilai UKG yang dimiliki oleh guru dibawah standah yang ditentukan oleh Kementerian Pendidikan dan Kebudayaan Direktorat Jenderal Guru dan Tenaga Kependidikan.

d. Analisis Mengenai Pengaruh Antara Variabel Facilitating Condition(FC) dengan Use Behavior

Pada Variabel facilitating condition berpengaruh terhadap variabel dependen user behavior. Hasil menunjukkan nilai t-statistik $4.171 \geq 1,65$ sehingga dapat disimpulkan terdapat pengaruh yang signifikan terhadap perilaku pengguna (user behavior) GPO. Hal ini sama seperti penelitian yang dilakukan oleh Handayani (2007) dan Sedana dan Wijaya (2009).Pada variabel konstruk facilitating condition tedapat satu indicator yang harus didrop yaitu FC3 memiliki nilai dibawah ketentuan yaitu 0,641 dengan pertanyaan saya memiliki pengetahuan yang dibutuhkan dalam menggunakan sistem guru pembelajar online (GPO) (missal : tahu mengoprasikan computer, tahu menggunakan internet), hal ini dipengaruhi oleh pengatahuan dari personal masing-masing akan menggunakan akses pada perangkat yang akan digunakan, mulai dari personal computer yang akan digunakan, jaringan internet yang dipakai.

\section{e. Analisis Mengenai Pengaruh Antara Variabel Behavioral Intention dengan Use Behavior}

Variabel behavioral intention berkontribusi untuk user behavior. Hasil menunjukkan tstatistik variabel berada dibawah ketentuan nilai yaitu 1.65 untuk nilai t-statistik behavioral intention yaitu $1.507 \leq 165$ sehinga bahwa variabel behavioral intention tidak berpengaruh signifikan terhadap perilaku pengguna (user behavior) GPO.

Penelitian ini dilakukan untuk mengetahui hubungan positif dari ke 6 variabel penelitian yang menjadi faktor-faktor penerimaan sistem terhadap perilaku pengguna sistem GPO. Dari penelitian yang telah dilakukan dengan 248 kuisioner yang telah disebarkan pada sekolah di Sekolah Menengah Pertama (SMP) di kota Palembang, hasil pengujian yang telah dilakukan pada setiap variabel penelitian menunjukkan bahwa hubungan antar variabel penelitian dan variabelEkspektasi kinerja (performance expectancy) berhubungan posistif terhadap behavioral intention, Ekspektasi usaha (effort expectancy) berhubungan dengan behavioral intention, facilitating condition berhubungan positif terhadap user behavior. Sebaliknya Faktor sosial (social influence) tidak berhubungan positif pada perilaku pemanfaatan dan penggunaan (Behavioral Intention) dan variabel perilaku pemanfaatan dan penggunaan (Behavioral Intention) berhubungan posistif dengan minat pengguna (user behavioral).Dari masing-masing konstruk estimasi model SEM dari hubungan pada setiap variabel penelitian yang dilakukan dengan kerangka kerja UTAUT, gambaran hasil penelitian dengan estimasi model SEM menggunakan software smartPLS ver 3.0.

Pengujian konstrak variabel social influence (SI) menunjukkan jika variabel social influence (SI) tidak berpengaruh terhadap minat pemanfaatan(behavioral intention) sistem Guru Pembelajar Online (GPO). Sedangkan pada variabel behavioral intention (BI) berpengaruh terhadap perilaku pengguna (use behavior). Hal itu menunjukkan jika perilaku pemanfaatan dalam penggunaan sistem GPO ini dipengaruhi oleh faktor minat dari masing-masing dari setiap guru untuk memanfaatkan sistem GPO dan perilaku pengguna sistem GPO ini tidak dipengaruhi oleh faktor social (social influence) dari teman kerja ataupun dari faktor sosial lainnya.

Dalam penelitian ini minat pemanfaatan (behavioral intention) teknologi oleh pengguna tidak berpengaruh terhadap perilaku pengguna (use behavior)sistem GPO. Hal ini 
menunjukkan jika pengguna GPO hanya mengikuti aturan dari pemerintah dalam hal ini kementrian pendidikan yang mewajibkan seorang guru untuk menggunakan sistem GPO. Sehingga harus adanya pendekatan secara personal dari pemerintah atau pimpinan terkait yaitu kepala sekolah dalam melakukan pendekatan terhapa guru dalam penggunaan dan pemanfaatan dari sistem GPO.

\section{KESIMPULAN}

Setelah melakukan tahapan proses penelitian dengan awal pengumpulan data, persiapan data dan analisis data, penelitian ini dilakukan untuk menganalisi tentang perilaku pengguna sistem dari guru-guru Sekolah Menengah Pertama (SMP) sebagai pengguna Sistem Guru Pembelajar Online (GPO) dengan menggunakan Model UTAUT. Dari penelitian hasil uji validitas dan uji hiputesa pada penelitian ini menunjukkan bahwa 5 konstrak penelitian, dari kelima kontrak penelitian terdapat empat konstrak yang berpengaruh signifikan yaitu performance expectancy (Ekspektasi Usaha) dan effort expectation berpengaruh terhadap behavioral intention dan facilitating condition dan dua variabel yaitu social influence tidak berpengaruh signifikan pada perilaku pemanfaatan dan penggunaan (behavioral intention) dan behavioral intention tidak berpengaruh positif terhadap user behavior sistem Guru pembelajar Online (GPO), dalam hal ini menunjukkan jika tidak semua factor dalam pengembangan sistem dapat diterima langsung oleh pengguna, pengembang dihadapkan dengan kendala-kendala yang terkadang menyangkut perilaku pengguna sistem.

Dengan adanya penelitian ini diharapkan Kementerian Pendidikan dan Kebudayaan Direktorat Jenderal Guru dan Tenaga Kependidikan sebagai badan pemerintah yang menaungi sistem pendidikan dapat melakukan sosialisasi tentang Sistem Guru Pembelajar Online (GPO) sebagai salah satu alat pemerintah untu meningkatkan konpetensi guru pengajar yang ada di Sekolah Menengah Pertama (SMP) terutama di kota Palembang sendiri.

Dengan adanya penelitian ini Kementerian Pendidikan dan Kebudayaan Direktorat Jenderal Guru dan Tenaga Kependidikan sebagai pengembang dari Sistem Guru Pembelajar Online (GPO) dapat lebih melakukan evaluasi terhadap sistem GPO sendiri dalam model pembelajaran ataupun dalam tampilan maupun sistem pada GPO, karena tidak semua pengguna GPO bisa dapat dengan mudah memahami apa-apa yang ada dalam sistem GPO. Selain itu juga penelitian ini dapat dijadikan referensiuntuk penelitian yang lain untuk lebih mengembangkan pada penelitian-penelitian selanjutnya.

\section{Referensi}

Alfianika, N. 2016. Buku Ajar Metode Penelitian Pengajaran Bahasa Indonesia. Deepublish.

Baroroh, K. 2011. Upaya meningkatkan nilai-nilai karakter peserta didik melalui penerapan metode role playing. Jurnal Ekonomi \& Pendidikan, 8(2).

Bendi, R. and Andayani, S. 2013. Analisis Perilaku Penggunaan Sistem Informasi Menggunakan Model UTAUT. Semantik 2013, 3(1), pp.277-282.

Bungin, B. 2006. Metode penelitian kualitatif.169 
Chin, W. W. 2010. How to write up and report PLS analyses Handbook of partial least squares. (pp. 655-690): Springer.

Curry \& Kerlinger, L.L.C. and Kerlinger, P. 2006. Post-construction avian and bat fatality monitoring study for the High Winds Wind Power Project, Solano County, California: two year report. Curry \& Kerlinger, LLC.

Djatikusuma, Edin, S., Herry Widagdo. 2015. Analisis Perilaku Calon Mahasiswa Terhadap Minat Untuk Menjadi Mahasiswa Di Sekolah Tinggi Ilmu Ekonomi Multi Data Palembang Menggunakan Metode Unifield Theory Of Acceptance And Use Of Tehnology (UTAUT). Program Studi Akuntansi. STIE MDP Palembang

Fatmawati, E. 2015. Technology Acceptance model (TAM) untuk menganalisis penerimaan terhadap sistem informasi di perpustakaanM INFORMASI PERPUSTAKAAN. IQRA': Jurnal Perpustakaan dan Informasi, 9(1).

Field, A. 2009. Discovering statistics using SPSS. Sage publications.

Hair, J., Black, W., Babin, B., \& Anderson, R. 2010. Multivariate data analysis (Vol. 7). Upper Saddle River, NJ: Pearson Prentice Hall.

Hair Jr, J., Sarstedt, M., Hopkins, L. and G. Kuppelwieser, V. 2014. Partial least squares structural equation modeling (PLS-SEM) An emerging tool in business research. European Business Review, 26(2), pp.106-121.

Hair Jr, J.F., Hult, G.T.M., Ringle, C. and Sarstedt, M. 2016. A primer on partial least squares structural equation modeling (PLS-SEM). Sage Publications.

Handayani, R. 2007. Analisis Faktor-faktor Yang Mempengamhi Minat Pemanfaat Sistem Informasi dan Penggunaan Sistem Informasi. Symposium Nasional Akuntansi.

Haryono, S. 2017. Metode SEM Untuk Penelitian Manajemen: Amos, Lisrel \& PIS. PT.Luxima Metro Media, Jakarta Timur

Kementerian Pendidikan Dan Kebudayaan, Direktorat Jenderal Guru Dan Tenaga Kependidikan. 2016. Guru Pembelajar, Pedoman Program Peningkatan Kompetensi, Moda Tatap Muka, Dalam Jaringan (Daring), dan Daring Kombinasi

Kline, R. B. 2010. Principles and practice of structural equation modeling (3rd ed.). New York: Guildford Press

Lam, F.F., Yeung, J.H., Chan, K.M. and Or, P.M. 2008. Dihydrotanshinone, a lipophilic component of Salvia miltiorrhiza (danshen), relaxes rat coronary artery by inhibition of calcium channels. Journal of ethnopharmacology, 119(2), pp.318-321.

Malhotra, N.K., Birks, D.F., Palmer, A. and Koenig-Lewis, N. 2003. Market research: an applied approach. Journal of marketing management, 27, pp.1208-1213.

Meyers, L. S., Gamst, G., \& Guarino, A. J. 2006. Applied multivariate research: Design and interpretation: Sage. 
Putra, G. and Ariyanti, M. 2017. Pengaruh Faktor-Faktor dalam Modified Unified Theory of Acceptance and Use of Technology 2 (UTAUT 2) terhadap Niat Prospective Users untuk Mengadopsi Home Digital Services PT. Telkom di Surabaya. Jurnal Manajemen Indonesia, 14(1), pp.59-76.

Sabihaini, Y.L., Astuti, W.T. and Abdullah, M.M.B. 2010. An Experimental Study of Total Quality Management Application in Learning Activity: Indonesia's Case Study. Pak. J. Commer. Soc. Sci, 4(1), pp.01-21.

Sedana, I.G.N. 2009. Penerapan model UTAUT untuk memahami penerimaan dan penggunaan learning management system studi kasus: Experential e-learning of Sanata Dharma University. Jurnal Sistem Informasi, 5(2), pp.114-120.

Sedana, I.G.N. and Wijaya, S.W. 2010. UTAUT model for understanding learning management system. Internetworking Indonesia Journal, 2(2), pp.27-32.

Sugiyono, D.R. 2006. Statistika untuk penelitian. Bandung: CV. Alfabeta.

Syamsuar, D. 2015. Understanding IPv6 resistance: A model of resistance among Indonesian organizations (Doctoral dissertation, Curtin University).

Yamin, S. and Kurniawan, H. 2011. Generasi Baru Mengolah Data Penelitian dengan Partial Least Square Path Modeling Aplikasi dengan Software XLSTAT, SmartPLS, dan Visual PLS. Jakarta: Salemba Infotek.

Yusrizal. 2008. Pengujian Validitas Konstrak Dengan Menggunakan Analisis Faktor. Jurnal Tabularas PSS UNIMED, Vol.5 No.1

Venkatesh, V., Morris, M.G., Davis, G.B. and Davis, F.D. 2003. User acceptance of information technology: Toward a unified view. MIS quarterly, pp.425-478.

Venkatesh, V., Thong, J.Y. and Xu, X. 2012. Consumer acceptance and use of information technology: extending the unified theory of acceptance and use of technology. MIS quarterly, pp.157-178. 